UJBM, Vol.2, No. 1, January - June 2003, pp 38-47

ISSN 0975-3311

https:/ / doi.org/ 10.12725/ ujbm.2.4

\title{
WOMEN ENTREPRENEURSHIP DEVELOPMENT IN SMALL SCALE SECTOR IN THE CONTEXT OF GLOBALISATION
}

\author{
Prof. D. Himachalam* and Dr. M. Shankara**
}

\section{Abstract}

With the impetus on entrepreneurial development in semi-urban and rural areas to solve the threatening unemployment crisis, women entrepreneurs have a major role to play. Women are found equally capable and given the right encouragement and support, they are bound to contribute in abundance towards the upliftment of the small scale and tiny sector.

The economic prosperity of India largely depends upon the success of her industrial and agricultural sectors. Owing to its limitations, the agricultural sector has not been able to contribute adequately to the nation's economic development. Therefore, the industrial sector has assumed greater importance in economic development. Realising this fact, our planners have aimed at speedy industrial development through harnessing the natural and physical resources that our country is endowed

\footnotetext{
* Professor \& Head, Department of Commerce, S.V.U.P.G. Centre, Kavali. E-mail: himachalam_dasaraju@yahoo.com

** General Manager (Commercial and LaQ), Industries Development Corporation Limifed, Bangalore. E-mail: shankar@kssidc.org
} 
with in plenty. They have also realised that the people and their potential ability have a supremely important role to play in the stupendous endeavour, and that any neglect of the human factor would enfeeble the economic prosperity of the country. Consequently the industrial policies of the government and the success Five-Year plans reiterate the government's intention to stimulate and promote the human factor in industrial development.

Waves of liberalisation, privatisation, and globalisation are sweeping across the world. Those who talked about 'market failure' and 'exclusion of the poor by the market' are now advocating a greater role for the market forces and market friendly economy. The growing needs of the public, on the one hand, and the inability of the Government machinery to cater to the ever-growing needs of the people efficiently and effectively, on the other hand, have accelerated the process of marketisation. Apart from these, the increasing public expenditure and resource crunches also have strengthened the bonds of privatization. This trend could be clearly seen in the field of industry and the business where the potential entrepreneurs come forward and take up industrial ventures. It is worthwhile considering what role the women entrepreneurs can play in this context.

Entrepreneurship is a vital input to industrial development as entrepreneurial talents and efficiency made the fortune of an enterprise. It is the spirit of the enterprise that makes one an entrepreneur. Entrepreneurs are those who initiate, organise, manage, and control the affairs of a business or industrial unit, and who confined the factors of production with supply of goods and services. They are the nucleus of economic activity and propellers of economic development. They are a dynamic force in the economic life of a society and have organised its productive resources. Entrepreneurship involves taking risks and co-ordinating the factors of production towards prosperity in an uncertain environment. As a matter of fact entrepreneurs and their entrepreneurial qualities make the difference in the success or the failure of an industrial organisation. The same has been widely realised by our planners owing to its importance in the industrial progress. There is a great need to bring out the latent energies and talents of prospective entrepreneurs and mould them into active entrepreneurs who are daring and prepared to take risks, and in situations of uncertainty and uncertain earnings. The development of right entrepreneurship is one of the most urgent and acute problems faced by a developing country. Lack of the right kind and number of entrepreneurs hinders economic development. The Government of India has undertaken a number of programmes to impart all sorts of technical, managerial and other related training to prospective entrepreneurs, so that they enter the industrial field confidently and competently, and manage the units scientifically. In entrepreneurship development it is very necessary to give equal importance to prospective women entrepreneurs. Women have all the potential 
for efficient entrepreneurship in any enterprise. The Government of India has recognised this fact and is encouraging women to take industrial activity.

Women have a predominant role to play in our economy and there is urgent need to bring them into mainstream of economic development in general and industrial development in particular. But they have not responded favorably to this call and the reasons for their hesitation is not far to seek. Accustomed as most of them are to the confines of the family and household, they are generally against assuming new roles for themselves, especially if they are regarded, though mistakenly as role appropriate to men only. As times have been changing, they should be motivated and encouraged to face themselves from the shackles of crippling customs and traditions, and to enlarge their field of activities. In view of their proverbial capacity for hard work, dedication, commitment and sense of duty and responsibility, they have to be properly motivated and their innate talents and ability nurtured and canalised into newer and fruifful activities and entrepreneurship. In the developed countries women's participation in various economic activities including industries has become a familiar fact. Such activities have ceased to be male prerogatives. In the interest of the nation's all round development it is necessary that Indian women, both urban and rural, be drawn into them without delay. They have now many profitable openings to exercise their talents and potentials, if only they venture out. There can be no doubt that they can make substantial contribution to the nations development. In the industrial field, the small-scale sector provides many opportunities for their entrepreneurship. More of it later.

As per the I.L.O's report of 1980, about 10 per cent of world's income and only 1 per cent of world's assets are received by women though they represent 50 per cent of the world's population and perform $2 / 3$ of the total work in the world. In India it is still far worse, though the women constifute 60 per cent of the rural unemployed and 56 per cent of the total unemployed. In the national scene, out of an overall 10 per cent increase in recruitment for government service, women comprise only 2 per cent. They form just 6 per cent in all civil services, and 7.5 per cent in Indian Foreign Service. In the forest service and police service, their number is even smaller. Obviously women are the most neglected and form the largest disadvantaged segment of the country. A draft of the National Perspective Plan for women for the period from 1988 to $2000 \mathrm{~A} D$ had mooted a wide range of proposals which included proper projection of women in the media, provision of thorough going legal safeguards for them, job reservalions, and anti-poverty programmes for women in various fields. It demanded all-round measures to ensure that women were brought into the mainstream of the socio-economic development of the country by the end of $2000 \mathrm{AD}$. The government has introduced several developmental programmes and other related schemes for imparting training, extension services 
to the women entrepreneurs to attract more women to the industrial activity. The government has also set up national level standing committee in September, 1985 on women entrepreneurs by the Ministry of Industry and also started various women development corporations for their development.

The Human Development Report, 1995 focuses on the gender inequality in the development process of various countries. It highlights that among the 900 million illiterates in the developing world, women are in far worse conditions than the men. Among the 1.3 billion people in poverty, 70 per cent are women. But, the invisible non-monitored contribution of women to the world output, is a staggering $\$ 11$ trillion per annum or nearly 50 per cent of the officially estimated world output of $\$ 22$ trillion. The report reveals that the women are placed unenviable in all countries, in all respects. Even in administrative and managerial cadres, women are far behind. In India, women accounted for 2.3 per cent of the employed in this cadre in 1992 and the rest merely occupied by men. Women in India are relatively powerless, and have very limited control over the resources of the country. The patriarchal ideology has encouraged their sub-missiveness, sacrifice, silent suffering, obedience, which have diluted women's participation in the economy. Father of the nation, Mahatma Gandhi asserted rightly: "My greatest hope is women. They want a helping hand to lift them out of the well in which they have been kept. They made a record contribution during Satyagraha of 1931-32, they are waiting to be organised." "Woman is the companion of man gifted with equal mental capacities. She has the right to participate in all walks of life along with man. She has the same right of freedom and liberty as man. She is entitled to a supreme place in her own sphere of activity as man is. By sheer course of vicious customs even the most ignorant and worthless men have been enjoying superiority over women for which they do not deserve and ought not to have."

In India and in other developing countries the ownership and management of business and industry have long been considered as the male prerogative. This situation is changing gradually and in recent years women have begun to participate in various economic activities including the fields of industry and business. Elite women in cities are making their way into non-conventional fields such as consultancy, marketing, advertising, export of garments, interior decoration, handicrafts, dyeing and printing, food processing etc.

\section{Need for Women Entrepreneurship}

The economy of our rural areas remains stagnant. As per the seventh plan estimates, almost 41 per cent of the rural population and about 20 per cent of the urban population live below the poverty line. This difference appears to be mainly due to 
the concentration of industries in urban areas. Most of the rural people are agricultural labourers who get employment only during the agricultural seasons. $A$ majority of agriculturists hold less than one heclare of land. Productivity in agriculture is still low and most of the small farmers are caught in the vicious circles of poverty and indebtedness. So agriculture by itself cannot provide full employment in rural areas. Unemployment in rural areas is increasing and migration from rural to urban is a great problem of the day. Estimates by the Planning Commission placed employment backlog at about 28 million by the beginning of Eighth Plan. The total requirement of employment during 1990 to 1995 would be about 65 million and during the decade 1990-2000, it would be 105 million. Out of the above employment seekers a major portion belongs to rural areas. Therefore, it is necessary to develop small-scale industrial units in areas where there is chronic unemployment, dearth of capital, lack of appropriate technical know-how, and certain inherent structural imbalance in the economy. As the small-scale sector has a high potential for employment generation, there is plenty of scope for the dispersal of industrial units to narrow down regional imbalances, utilisation of untapped local available resources and for the promotion of entrepreneurship among women. Towards this end the Government of India has tried to promote financial and managerial assistance.

In India, women constitute $60 \%$ of the rural unemployed and $56 \%$ of the total unemployed. It means that a very substantial portion of women is unemployed though they have the ability to undertake varied activities including industrial activity. In this context it is essential to develop women entrepreneurship in order to expose them to various employment and profit-generating avenues. And it is a fact that in some parts of our country, women have proved and established their talents as successful entrepreneurs. But this development has taken place in cities only. Rural women, as they are caught in the web of poverty, social traditions and restricting customs, it is very necessary to emancipate them and bring them into the hold of entrepreneurship.

\section{Avenues for Women Entrepreneurs}

Women can venture into any area of business and industry depending on their interest and area of specialisation. This depends upon their educational background, family, social status, income level, nature of training, technical knowledge, entrepreneurial background and so on. Women can venture into industry, business or other activities by getting trained in entrepreneurship in the related areas. In this context the government and allied agencies are providing training facilities through various Entrepreneurship Development Programmes (EDP's). Financial institutions are also directed to purvey financial and managerial assistance to women 
entrepreneurs. Women can select for their investment a unit in the small-scale sector, cooperative sector or the Khadi and Village Industries Sector.

\section{Small Scale Sector}

The small-scale sector is a major area in which enthusiastic, talented women can start a number of small units. The field is vast and as many prospective women entrepreneurs as can venture. It provides avenues in various areas where raw material and labor and other infrastructural facilities are abundantly available. It is easy to start units in this sector as it depends totally on locally available resources. All entrepreneurs who are prepared to invest upto Rs. 75 lakhs in fixed assets can register a small-scale unit. Those who can invest upto Rs. 10 lakhs in fixed assets can sfart a tiny unit in rural and backward areas. There is fair evidence of women by themselves managing small and tiny sectors very successfully. It is the commitment, hard-working, risk-bearing nature of women that makes the fortune of their units and enables them to march towards progress. As the women are still in a male dominating environment, it needs some effort to break their shackles to prove themselves as successful entrepreneurs. As small units are labour intensive based on indigenous technology, local available resources, flexibility in changing the product line, it is not difficult to succeed in this sector. Once women established themselves as successful entrepreneurs, they can provide good employment opportunities to a considerable number of unemployed educated women. They can start units in the manufacturing sector as well as the service sector in which there are several approaches for prospective women entrepreneurs.

\section{Rural Industries}

Rural industries have a vital role in the development of rural areas, which are generally associated with agriculture. Any industry located in a rural area where the population does not exceed 10,000 which intends to manufacture goods and render services with or without using power and in which the fixed capital investment per head does not exceed Rs. 15,000 can be considered as rural industry. Women can start any of the following industries:- hand made papers, bee-keeping, blacksmithy, carpentry, bio-gas, making of palmgur, non-edible oils, and soaps, gur and khandasari, agarbathi, fireworks, cottage matches, leather goods, cereals and pulses processing, fruit-processing and reservation, bamboo and cane work, gums, weaving of door-mats, bags, manufacturing of candles etc. Rural industries require limited capital. As they are to be located in rural areas where labour is available in plenty, women can successfully start their units. Village industries have high potential for employment generation, as they use locally available material 
and local labour. Their capital requirement is limited and they do not require any sophisticated technology. Therefore women can find in them a viable and profitable avenue for their development.

\section{Institutional Support}

To foster women entrepreneurship in our country, a number of institutions have launched special programmes and schemes with a variety of packages. They are intended to provide financial as well as managerial support to women entrepreneurs to set up their units in areas of their interest. The Government of India canalises assistance through these institutions for developing their ventures. The following institutions are working for women entrepreneurship development:

- Canara Bank Centre for Entrepreneurship development for women (C.E.D),

- S.B.I. Sthree Shakthi Scheme

- A.P.S.F.C. Women Entrepreneurship Scheme,

- I.F.C.I. interest subsidy scheme,

- I.D.B.I. Mahila Vidya Nidhi Scheme.

\section{Women Associations}

Women entrepreneurs belong to trade, industry, profession have been mainly confined to making representations to the decision-making machinaries of the central and the state governments in our country. With the advent of entrepreneurial wave in the country a few associations of women entrepreneurs have emerged to work for and creating a congenial atmosphere for the development of entrepreneurship in rural and urban areas. These associations are both international and national.

International Associations include

Associated Country Women of the World (ACWW)

World Association of Women Entrepreneurs (WAWE)

National Associations inlcude

Women Entrepreneurs Wing of National Alliance of Young Entrepreneurs

Association of Women Entrepreneurs of Karnataka

Self-employed Women Association of Ahmedabad.

Indian Council of Women Entrepreneurs, New Delhi 
The Indian Institute of Marketing Management

FICCl Ladies Organisation

National Standing Committee on Women Entrepreneurs.

\section{Barriers of Women Entrepreneurship}

It would be wrong to assume that it is all smooth sáling for women entrepreneurship. In India women entrepreneurs face several challenges and problems, internal as well as external, in managing their units. Despite the measure taken by the government and others, the problems persist. To list some of them at random:

I. Severe competition from the units managed by male entrepreneurs, ill treatment from their male counterparts.

II. Non-availability of raw material. This is a very different problem to all entrepreneurs, women in particular. To get the raw material in required time is not easy in our country. The prices of raw material also are high.

III. Financial constraints. Getting required financial support is a big problem to the women entrepreneurs. They are not getting the required financial assistance at concessional rates. Without adequate financial resources, they cannot function at all. Availability of sufficient financial assistance is the index of industrial development of any country.

IV. Problems of managerial deficiency. Women entrepreneurs should be provided managerial assistance in all the functional areas of industry.

V. Technical know-how is another problem to the women entrepreneurs. Technical advancement alone in the industrial sector enables progress in production, cost minimisation, and profit maximisation. Therefore the entrepreneurs should be facilitated with the latest technology in their respective areas of working.

VI. Women entrepreneurs have yet to get used to economic and social risks. In industry or business, entrepreneurs are constantly exposed to infinite risks and uncertainty. The success of an entrepreneur depends on her capacity to absorb additional risks arising out of her business activity. The higher the risk bearing capacity and confidence in meeting the uncertainties, the higher will be the profitability and progress of the venture. Women will have to learn to transfer their innate capacity to face risks and uncertainties in the domestic sphere to the sphere of industry and business.

VII. The sense of inferiority in women fostered by custom is a great barrier to their entrepreneur skill. They will have to overcome it by determinant effort. 
VIII. Lack of specialised training, to the women particularly in rural areas, hinders the progress of units managed by women entrepreneurs.

IX. Lack of sufficient infrastructure facilities is also a discouraging factor for women entering the industrial sector.

$X$. Lack of proper encouragement from the government by the way of special incentive packages exclusively for the women entrepreneurs.

Enough has been said about the steps taken by the government and other agencies to encourage and promote entrepreneurship among women, particularly in the small-scale sector. It has also been seen how certain pressing problem persists which are not easy to solve. It is necessary to take a realistic view and consider how best entrepreneurship of women can be fostered. Both the government and the entrepreneurs have fallen short of expectations. In spite of the measures taken by the Government for creating a congenial atmosphere to encourage women entrepreneurs, the development of their entrepreneurship in our country is still far behind expectations.

The overall industrial situation in our country is discouraging particularly in the small-scale sector where a majority of the units are in a moribund state, because of a conspicuous lack of managerial and innovative skills. Above all, the entrepreneurs are afraid that all small units will land in troubles due to industrial sickness, which is a quite serious problem in India. This situation naturally discourages prospective entrepreneurs, particularly women. Therefore, it is absolutely necessary that the entrepreneurs are properly motivated, encouraged, trained in technical and managerial skills, and provided with adequate financial resources for their successful functioning. It may be taken as axiomatic that there can be no industrial development at all without a commensurate development of entrepreneurship in the small-scale sector particularly among women. While the Government has become aware of the need to develop women entrepreneurship and has taken several sieps to promote it, the desired results have yet to be achieved. Part of the blame for it should lie with the prospective entrepreneurs themselves and part with the milieu in which they find themselves.

If lack of will power, self-confidence, proper motivation, foresight, lack of awareness of opportunities, managerial skills, technical and financial support, and want of family and community support etc. stand in the way of a woman entrepreneur, cumbersome formalities in starting an industry, lack of required infrastructual facilities, and assured marketing for their products, absence of proper training and encouragement from the Government, financial and other related agencies etc, discourage them from entrepreneurship. This situation has to be remedied if 
there should be rapid ind ustrial development. It is a dire need in the global context to bring the women into the mainstream of industrial development by providing proper motivation, help and encouragement in all respect. It is true that if the women come out with all commitment and dedication into the industrial scene nothing can foil their efforts in their success. It will go a long way in reshaping the industrial development of our couritry in the new Millennium. 